\title{
Con Confianza: The Emergence of the Zone of Proximal Development in a University ESL Course
}

\section{Con confianza: el surgimiento de la zona de desarrollo próximo en un curso universitario de inglés como segundo idioma ${ }^{*}$}

\author{
Sandra L. Soto-Santiago \\ sandra.soto@upr.edu
}

Rosita L. Rivera

rosita.rivera1@upr.edu

Catherine M. Mazak

catherine.mazak@upr.edu

University of Puerto Rico, Mayagüez, Puerto Rico

This article illustrates how a classroom community characterized by confianza-a feeling of mutual understanding, respect, and emotional closeness_facilitated the English language learning of Spanish-speaking students in a content-based English as a second language class at a Puerto Rican public university. To understand the processes by which this language learning took place qualitative data were collected through classroom observations and focus groups. The authors examined the language choices students made in their interactions with professors, teaching assistants, and peers as they engaged in classroom conversations using both Spanish and English as learning tools. The central claim of the article is that confianza created the conditions through which learners were able to activate their zone of proximal development.

Key words: English as a second language, higher education, Puerto Rico, zone of proximal development.

Éste artículo ilustra como en un salón de clases caracterizado por confianza —un sentimiento mutuo de entendimiento, respeto y cercanía - se facilitó el aprendizaje del inglés para estudiantes universi-

* Received: August 22, 2014. Accepted: January 9, 2015.

How to cite this article (APA $6^{\text {th }}$ ed.):

Soto-Santiago, S. L., Rivera, R. L., \& Mazak, C. M. (2015). Con confian₹a: The emergence of the zone of proximal development in a university ESL course. HOW, 22(1), 10-25.

This article is licensed under a Creative Commons Attribution-NonCommercial-NoDerivatives 4.0 International License. License Deed can be consulted at http://creativecommons.org/licenses/by-nc-nd/4.0/ . 
tarios puertorriqueños y cuyo primer idioma es español, en un curso de inglés como segundo idioma. Las investigadoras recopilaron datos a través de observaciones y grupos focales para examinar las selecciones de idioma de los estudiantes en interacciones con sus profesoras, asistentes de cátedra, y compañeros, en sus conversaciones dentro del salón de clases, utilizando tanto inglés como español como herramientas de aprendizaje. Argumentamos que la confianza creó las condiciones para que los estudiantes pudieran activar su zona de desarrollo próximo.

Palabras clave: educación superior, inglés como segundo idioma, Puerto Rico, zona de desarrollo próximo.

\section{Introduction}

Language learning is a social process; that is, it takes place in a specific context and by means of interaction between people (students, teachers, and others). Within this sociocultural understanding of language learning and language use, the community of learners is integral to the learning process (García, Flores, \& Chu, 2011; Reyes, 2009). This ethnographic case study illustrates how a classroom community characterized by confianza-a feeling of mutual understanding, respect, and emotional closeness - facilitated the emergence of the zone of proximal development (Vygotsky, 1978) and the English language learning of Spanish-speaking students in a content-based English as a second language (ESL) class at a Puerto Rican public university. To understand the processes by which this language learning took place, we examined the language choices students made in their interactions with professors, teaching assistants (TAs), and peers as they engaged in classroom conversations using both Spanish and English as learning tools (García \& Li, 2013). Our claim is that confianza created the conditions through which leaners were able to work in their zone of proximal development. We will illustrate this claim by analyzing the language learning strategies employed by students in the zone. Importantly, these learning strategies were bilingual, yet they facilitated the development of English.

\section{English Language Learning in Higher Education in Puerto Rico}

Puerto Rican students enter higher education with diverse English language proficiencies. Though educational language policy mandates that English be taught as a "special subject" in K-12 preparation in public schools, the resulting language proficiencies of the students vary greatly. In addition, a large number of students come to the university from private schools, which also represents a range of exposure to English and of learning experiences in this language (Maldonado, 2000). The university where this study took place deals with these varying proficiencies by placing students into "tracks" based on their scores on the English portion of the College Board (the ESLAT or English as a Second Language Achievement Test). 
All academic programs at the university require students to take four semesters of English classes. However, students with extremely low ESLAT scores are placed into a "remedial" track, which requires them to take five semesters of "basic English" instead of four.

In their university studies outside the English department, students use English to varying degrees. According to university policy, the medium of instruction of courses is determined by the professor, and so students may study content through both English and Spanish in a variety of combinations (Spanish medium with English textbooks and Spanish assessments; Spanish medium with English textbooks and English assessments; English medium with English textbooks and English assessments, among other combinations). All students will encounter at least some if not many academic readings in English during their university studies outside of the English class.

The curriculum for the remedial track courses focuses on grammar and vocabulary, with an emphasis on reading comprehension. This curriculum contrasts sharply with the actual demands placed on students' English in their content courses. For example, readings in the Basic English courses are generally about one page long and come from non-academic, sometimes authentic, sources such as newspapers and blogs. In contrast, this same student, during the same semester, is required to read entire chapters of a chemistry textbook in English, or academic articles from scientific journals in English (Mazak \& Herbas-Donoso, 2014). The pilot content-based English curriculum described in this study was designed in part to address this mismatch.

Students placed in pre-basic courses often express frustration with English due to the fact that they have supposedly studied the language for 12 years during elementary and secondary school and are still labeled low proficiency. Students themselves tell professors "Yo no bablo inglés" [I don't speak English] or "Yo no se mucho inglés" [I don't know much English]. Students' fear of the language is often perceived by professors who find (1) a lack of participation in their classes, (2) students' reluctance to answer in English when called on, and (3) a general silencing of students that is indicative of their discomfort in the English class. Classes taught in English-only often "lose" students as they completely disengage because of a lack of understanding. However, students are not what have been called "true beginners;" that is, they do have a fairly solid base in English. In fact, Puerto Rican Spanish has appropriated many English words that are a regular part of colloquial Spanish (Torres González, 2002), putting Puerto Ricans at an advantage over other English learners. In addition, even rural Puerto Ricans interact with English texts quite frequently (Mazak, 2008) and have access to English language television. The challenge for professors at this level is to activate students' existing knowledge and build on it in order to show students that they know more English than they think. Only if students feel comfortable with their instructor and classmates are they able to use what English they know, and so the pilot course described in the next section was designed to promote this comfort, in part by the acceptance of bilingualism in the classroom. 


\section{English for Agriculture Majors}

The campus where the study took place is the only one granting bachelor's degrees in agriculture in Puerto Rico. Agriculture majors are over-represented in the English remedial courses, yet the English demands of their degree program are similar to other science majors on campus (reading textbooks and academic articles in English). In addition, spoken English is important for participation in internships with the United States Department of Agriculture (USDA) and other federal agencies, experiences that often set candidates apart and help them obtain employment. Once they have a job, agronomists often find they, in fact, need to use English, whether they work in or outside of Puerto Rico, as most agriculture jobs are with multi-national corporations or US federal or state agencies. Thus, the English language needs of agriculture majors are just as great as those of any other student on campus; yet they are, as a group, under-prepared in English.

The researchers created a program, funded by a USDA Hispanic-Serving Institutions Education Grant, targeting low-English-proficiency agriculture majors for a three-semester content-based curriculum. The program followed the same sequence of courses at the basic level utilizing agriculture content. The first semester was an intensive four-week summer session equivalent to the pre-basic English course; the second and third semesters took place during the fall and spring semesters of the students' first year. During that year they took the first and second part of the Basic English course, still as part of our content-based English curriculum in agriculture.

There are four main factors to which we attribute the development of confianza in our program. These are relationship building, fluid physical space, our emphasis on bilingualism, and lastly instructor availability and instructor-student rapport. We argue that confianza was created as a result of these factors, which facilitated students' learning. In the results section we will provide further discussion of each factor and provide evidence from the data that links the development of confianza to these four factors. In the next section, we describe in greater detail our use of the term confianza and situate this term theoretically.

\section{Theoretical Frame}

\section{Defining and Situating Confianza}

Various scholars have explored the feelings of mutual respect, family-like personal bonds, and the close sense of trust between people in relation to the learning and sharing of knowledge, from an anthropological stance. Vélez-Ibáñez and Greenberg (1992) described confianza as the mutual trust and reciprocity that develop between individuals in zones of comfort. Moll, Amanti, Neff, and Gonzalez (2005) drew on this notion in their funds of 
knowledge study, mentioning confianza as "mutual trust" that is, essential to the reciprocal practices of knowledge exchange, which provide contexts in which learning can occur. Similarly, familia has been discussed by Cook-Gumperz and Szymaski (as cited in Reyes, 2009), as a way in which Spanish-speaking children described the relationships among students during group work in classrooms. Our notion of confianza in the classroom draws from the concepts mentioned above. However, in our study, we used and adapted the term confianza to honor the definition in our particular setting as described by the students. Throughout the study, students used the term confianza to describe the environment and the interactions in the classroom.

The Spanish word confianza could loosely be translated as "trust," but as this quote from one of the participants in the study explains, it is more nuanced than that.

La confianza es un término que se define como aquel espacio que se dan entre personas y que cada persona lo respeta entre siy que a su vez comparten ese espacio alpunto de que ambaspersonas estén de acuerdo con lo que se está baciendo y así yo defino confianza en el grupo... En este curso la confianza ba sido un punto clave de todas las actividades que se han becho y de la manera que nos tratamos todos pero siempre se respeta ese espacio porque hay confianza pero hasta cierto punto.

[Confianza is a term that is defined as the space that is formed among people and that is respected by each person that is part of it and that shares that space to the point where both individuals agree with what is being done and that is how I define confianza in the group...In this course confianza has been a key aspect of all the activities that we have worked on as well as the way we treat each other, but we always respect that space because there is confianza, but only to a certain point.]

According to the participants in our study, confianza is more than trust. Having confianza with someone means feeling comfortable but also supported. Confianza means familiarity and ease but always characterized by respect. When there is confianza individuals are never taken advantage of in a negative sense; instead, it creates an environment where development and growth occur among those who share the confianza.

\section{Confianza and the Zone of Proximal Development}

Though our understanding of confianza is derived from anthropological research, we use it to explain what Moll (2013) calls the "emergent dynamic" of classroom interactions. To fully understand the learning mechanisms embedded in these classroom interactions, we turn to Vygotsky's notion of the Zone of Proximal Development (ZPD, or simply, "the zone"). Lantolf (2000) defines ZPD as: "the difference between what a person can achieve when acting alone and what the same person can accomplish when acting with support from someone else or cultural artifacts" (p. 17). Eventually, the learner should be able to use new strategies and recontextualize them (self-regulation). Literature has shown that students 
working collaboratively and bilingually scaffold for each other, which facilitates self-regulation in which language learning strategies are internalized through the use of both languages (Reyes, 2009). Moll (2013) emphasizes change, and "deliberately creating new circumstances where change can occur" as "central to the concept of the zone." He further states, "the zone is designed, one could say, to facilitate analysis in action. The goal is not only to facilitate particular outcomes but also to generate specific mediating processes as objects of study" (p. 10). Through this paper, we show how the zone emerged precisely because confianza had been established in the classroom, in part because of circumstances that we created "deliberately." Thus, the relationship between confianza and the zone is that confianza, which emerged organically from teacher, student, and contextual interactions, activated the zone, which in turn facilitated language learning.

The emphasis on the emergent aspect of the zone-that through social interactions facilitated by confianza, the zone emerged and facilitated student learning-is key here. Our experience in this study echoes Moll's (2013) description:

The outcomes emerged from the fluid social relations and forms of discourse brought to the task, which constituted the zone. We certainly had an idea of what we were doing, and how our bilingualism might help the students, but we could not predict the nature of the interactions: These were negotiated and constituted in situ by the relational features of the zone. What the zone offers through its mediations is a range of possibilities for the development of learning and the formation of new subjectivities for teachers and students. In this kind of zone, teachers are also learners and students are also teachers. (p. 10)

Again, we argue that the "fluid social relations and forms of discourse," which are characterized by confianza, constituted the zone. This confianza, developed "in situ," was facilitated by the four factors mentioned above. Though, like Moll (2013), we "had an idea of what we were doing," as evidenced in the four factors describing our program design, the relationships that developed were negotiated and quite spontaneous. Confianza, we argue, allowed for learner control over language use to process new knowledge. In other words, confianza led to the creation of the zone, which facilitated language learning. We develop a detailed description of these processes below.

\section{Method}

The ethnographic case study reported here originally began as a way of assessing our implementation of the English curriculum for agriculture majors. As part of our self-assessment, we conducted focus groups with the thirty student participants (five groups of six students) at the end of the first of the three courses. The focus groups' discussions were transcribed and analyzed using the open and focused coding techniques described in Emerson, Fretz, and Shaw (2011). In this process all participant names were replaced by 
pseudonyms to ensure participant confidentiality. In these focus groups, the students themselves used the term confianza to describe the relationship between participants in the project, including professors, TAs, and fellow students. They linked confianza to why they enjoyed the class and learned more English compared to previous English courses.

Noticing that the classroom dynamic they described was somewhat unusual, we decided to pursue the mechanisms by which confianza facilitated language learning. To this end, in the second semester of the three-semester program, we began taking ethnographic field notes of classroom interactions. Ethnographic field notes were taken beginning at the end of semester two and throughout semester three, for a total of four months. The TAs, acting as participant observers, alternated taking field notes three times a week, during the fifty minutes in which the class met, for approximately 48 hours of observed classes. Students were aware that observations were taking place during the class, although they did not know what we were specifically inquiring about. In order to validate the classroom observations as well as the focus group results, the research team conducted open-ended interviews with participants in the third semester. We selected nine students for interviews. This selection was based on: (1) their performance in class (a range of performances were chosen), (2) topics discussed in the focus groups, and (3) our interest in their previous English learning experiences. The individual interviews focused on students' prior English classes, their exposure to English in schools and at home, and their perceptions of English at the time.

\section{Field Note Analysis}

The field notes were transcribed from jottings into fleshed-out notes in a word processor. Each week sections of field notes were assigned to members of the research team, which consisted of the two professors, the TAs, and an undergraduate researcher. Before the meetings, each researcher would open-code her section of the field notes and we met on a weekly basis to discuss this open coding. After initial open -coding, researchers noted that confianza emerged as a recurrent theme in the data. The classroom dynamics documented in our field notes during our observations showed that students, professors, and TAs had developed confianza in the classroom, and that this confianza was key to the language learning strategies that our students used when they completed work in class. In focused coding, we particularly coded for how confianza played a role in the different types of help students got from professors, TAs, and other students. At this point, we decided to code for "helping events," which simply were any instance of students getting or giving help during language learning. In the last step of our analysis, we tried to understand the analyzed helping events through the lens of Vygotsky (1978). The learning strategies employed by the students, combined with the environment characterized by confian 2 , fostered student-initiated helping events that occurred within the zone and facilitated second language learning. 


\section{Results}

In this section, we describe and explain how first year university students learned language in the zone during the content-based English for agriculture majors class. As mentioned above, the zone emerged in situ because of the confianza that developed among participants in the class. First, we provide evidence from our data that (a) there was indeed confianza in the classroom and that (b) confianza led to the emergence of the zone.

\section{Evidence of Confianza}

Four factors related to the design of the program (described above) contributed to the development of confianza: (1) relationship building, (2) fluid physical space, (3) emphasis on bilingualism, and (4) instructor access and rapport. In interviews and focus groups, students described these aspects of the program in further detail, linking them to the development of confianza. We also saw evidence of confianza in our field-note observations of the classroom.

Relationship building. Our group of students shared the same major and took other classes together. Hence, their relationship was not solely based on our program. This contributed to their feeling comfortable while collaborating in class, which included sharing knowledge and strategies with each other. Students consistently expressed during the interviews how working in groups and using Spanish in class allowed them to clarify questions while working on a given task. While discussing the most beneficial aspects of the class, Lester mentioned that group dynamics helped him to "clarify doubts" about vocabulary.

Como que uno compartía [en el grupo] y las dudas — como que las diferencias que uno tenía en vocabularios_por ejemplo, a veces uno decia, "ay yo entiendo esta palabra" cuando la leía pero cuando te dicen el significado no era lo que tú pensabas y otra persona tenía la duda y pues abi tú la aclaras. (Lester)

[It's like we could share [in the group] and the doubts-like the differences that you have in vocabulary — for example, sometimes I would think, "Oh, I know the meaning of that word," but when they tell you the meaning, it was not what you thought and if someone else had the same doubt that way you can clarify it.]

The group dynamics helped Lester because he felt that he was getting support by working with his classmates. This quote shows that Lester trusted his group mates because he reveals to them that he has "doubts" about the meaning of words, and takes this as an opportunity to clarify them. This kind of sharing — of admitting what one does not know is evidence of confianza among members of the group.

Fluid physical space. Our observational data showed that students took advantage of the facility with which they could turn their chairs and move around the room. Because the classroom was furnished with tables and chairs with wheels, students could easily form 
groups with a quick turn of their chairs. They often did this without the prompting of instructors, as noted in this excerpt from the field notes:

Adrián, Alberto and Ismael moved, turned around, without being ordered to pair with Jessica and Gloria. (Field notes)

Students are given their laptops. Students are given a handout. Cathy explains the project. Leyla walks to Yesenia's table and asks “¿Puedo trabajar con ustedes?” [Can I work with you?]. (Field notes)

These field note excerpts showcase how students moved around in the room to work with those with whom they felt more comfortable. Students relocated themselves into small groups based on the activity or task at hand, often without being told to do so by the instructors. In other words, when an activity was announced, they simply assumed they would work on it together and moved themselves into the group they wanted to work with. Because the program was three semesters long, these small groups were well-formed and consistent semester after semester. The fact that students formed groups without instruction showed the confianza not only between the students and the professor, but also between the small groups themselves as students just assumed their group positions and thus included the fellow students whom they had become close to. In addition, the TAs were well-distributed around the room, and students felt they could find help quickly regardless of where they were sitting.

Emphasis on bilingualism. As mentioned above, students in general who are placed into the basic level are anxious about their English proficiency. For this reason, it was fundamental that Spanish was accepted in the classroom as an additional means of communication with peers and staff during all activities. Students understood the necessity to be able to ask questions in Spanish in order to complete their tasks in English. One student explained it this way:

La profesora entendió bien nuestra necesidad [de usar español], que no es lo mismo que uno tiene la opción de preguntar en español porque realmente si uno no se sabe expresar en inglés, pues no va a baber una comunicación efectiva y por lo menos con eso nunca bubo problemas, por lo menos fue consistente. (William)

[The professor understood well our need [to use Spanish], that it's not the same to have the option to ask in Spanish because in reality if you don't know how to express yourself in English, well then there is not going to be effective communication and at least with that there was never a problem, it was always consistent.]

The use of both Spanish and English in the classroom emerged organically; that is, because the professors believed in acknowledging bilingualism and opening channels of communication with students, they encouraged Spanish use in the classroom. From the beginning, Spanish was used by all staff, which signaled to students that Spanish use was acceptable. This built confianza in the classroom as students were not silenced; on the contrary, they felt that they could use Spanish in their pursuit of learning English. 
Instructor availability and instructor-student rapport. In focus group interviews, students characterized their relationships with the professors and staff as relationships of confianza. Carlos described the relationship among the students and professors as sharing a "professional-student space:"

La profesora siempre ha compartido un espacio, al igual que el staff, de profesional a estudiante pero ese espacio nos lo hacen más ameno y no nos distancian de una manera tan arcaica como en esto momentos lo hacen muchos profesores donde yo soy profesor y usted es estudiante y usted me responde como un estudiante hacia un profesor. (Carlos)

[The professor and staff have always shared a professional-student space with us but they make that space more pleasant and do not distance us in a way as archaic as many professors do nowadays where I am the professor and you are the student and you respond to me as a student should to a professor.]

In other words, the relationship between professor and student was "professional" but not overly or "archaically" distant. The student felt closeness and easiness with the professor characteristic of a relationship of confianza.

William pointed out that the professor never made them feel bad about their mistakes and emphasized trying:

Pues me senti cómodo porque a pesar de que uno realmente comete unos errores graves Catby nunca nos juzgó ni se burlabay tampoco nos perjudicó en las evaluaciones habiendo a veces errores que eran perjudiciales en los exámenes y en los trabajos. Ella lo que decía era "aprendan inglés, si cometen errores está bien, eso no les va a afectar, pero inténtenlo." (William)

[Well, I felt comfortable because although you make really huge mistakes Cathy never judged us or made fun of us and it never affected our grades, although there were times when we made significant mistakes that could have hurt us in the exams and assignments. What she would say was

"learn English, if you make mistakes it's OK, it's not going to affect you, but just try."]

This rapport between professor and student, where students felt close to the professors and that it was acceptable to make mistakes, was an important factor in developing confianza. It is important to clarify that William was referring to the initial stages of the course where staff encouraged students to write and speak English without worrying about grammatical mistakes as a strategy to help them feel comfortable and to understand that we all make such mistakes. This does not mean that instructors undermined the importance of grammar but rather that they chose to first focus on getting students to feel comfortable while writing and speaking in English without feeling the pressure of getting a bad grade for making mistakes.

\section{Confianza and the Emerging Zone}

As shown in the previous section, students emphasized trust, fairness, and comfort as characteristics of the classroom. This led to an overall feeling of confianza. This confianza could be observed in student behaviors and, we argue, led to the emergence of the zone. In this section, we use the observed characteristics of confianza to organize examples of language 
learning strategies in the zone. We saw confianza in the following characteristics of classroom interaction: (a) accepting help from professors, TAs, and peers, (b) the unsolicited sharing of information, and (c) informal discourse used with everyone (regardless of whom the student was addressing). Excerpts from the field notes are provided as examples of these classroom behaviors that we argue are evidence of confianza and of strategic learning activities in the emerging zone.

Accepting help from professors, teaching assistants, and peers. Although the TAs and the professor were always willing to help the students by clarifying their questions, repeating instructions, and translating words, it was impossible for them to assist every student every time help was needed. Sometimes the TAs and the professor were busy helping other students. The confianza students had with one another led them to offer and accept help among themselves. This is no small feat within this particular group of learners, who, as mentioned above, have been labeled as low-English proficient and struggled with owning their English language skills. The following field-note excerpt illustrates one case where students felt the confianza to offer and accept help from each other:

William observed that Lester had been asking Sandra (the TA) about a sentence and she had not been able to help him yet because she was assisting several students. William approached Lester and provided him with feedback on how to improve his sentence, while Lester continued to ask William questions. When Sandra was finally able to approach Lester, he told her that he was fine because William had already explained to him how to fix the sentence and that he now understood it well.

Because students had confianza with one another, they could share their knowledge through helping in the emerging zone.

Students felt very comfortable requesting information and receiving help from the TAs, who circulated around the room during classroom activities for that purpose. However, as the next example shows, they also had the confianza to jump in and help fellow students during their interactions with the TAs. Consider the following excerpt:

Lester wanted to know the English translation for the word era, for which he called Sandra. She explained to him that era is the past tense of the verb $i$, then waited for him to come up with that form. Sandra was trying to help Lester find the word by himself; in the meantime, William, who was seated next to Lester interrupted and said "was."

Lester's language learning benefits from the confianza he has with his peers. Not only does he have Sandra trying to help him, he also has William offering help. Because of confianza, William's help is accepted and not seen as intrusive or offensive. At the same time, students are operating in the emerging zone.

An additional example of confianza in the classroom was the way in which students often used "double-checking." Double-checking, in our case, refers to calling out questions for 
which the asker is quite sure of the answer, just to double check that s/he has it right. In a classroom setting with less confianza, this type of calling out could be met with ridicule from fellow students, or seen as disorderly or rude by TAs and professors. However, in our case, confianza allowed for this type of double-checking during classroom activities. Students' double-checking questions helped to organize their language learning into memorable chunks, and because the questions were called out, other students could benefit from them as they worked. For example, when a student called out to a TA, "¿Business no es negocio?" [doesn't negocio mean business?], everyone around that student heard this and the meaning of the English word "business" was reinforced. Another example of this type of double-checking occurred when students were learning the word "unique." A student asked a TA, “¿verdad que hay una tienda que se llama asi?" [Is it true there's a store that's named like that?], thus connecting the word to a frequently seen store name. This double-checking, facilitated by confianza, became a way in which students shared language learning strategies in the emerging zone.

Unsolicited sharing of information. The help that students gave each other was often unsolicited (as in the excerpt above where William provided Lester the past tense form "was" for "era"). This is evidence in itself of confianza, as only students with that kind of relationship could offer help without being rejected. This unsolicited, open sharing of language learning strategies is also evidence of the emerging zone. This becomes clear in the following excerpt where Pepe helped Lester distinguish between "before" and "after" by thinking about the movie titled The Day After Tomorrow.

Lester: ¿Qué significa after? [What is the meaning of the word after?]

Sandra: After es después, before es antes. [After means después, before is antes.]

Pepe: ¿Tú sabes cómo yo me acuerdo? Con The Day After Tomorrow.

[Do you know how I remember? With The Day After Tomorrow.]

The interaction between these two students is an example of how participants were able to communicate with one another in order to ask and answer questions based on their own level of trust. Lester did not need to raise his hand to ask for information and Pepe, who responded, was able not only to answer promptly, but also to provide his classmate with a strategy to remember these lexical items. The background knowledge that Pepe provided (the reference to the movie The Day After Tomorrow) was unsolicited, but modeled a strategy for remembering the terms in English. In this event Pepe felt the confianza to share his non-academic strategy with Lester. Again, this strategy-sharing happens in the emerging zone.

Informal discourse. The informality of students' discourse in the classroom emphasized the trust inherent in a relationship of confianza. For example, students often asked the TAs for help during a lesson - even using the TAs as resources at the same time that the professor was delivering class material. During a discussion of an upcoming assignment where students had to 
interview agronomists about their jobs, the professor was explaining in English the meaning of the word "hiring." When she was finished, a student translated her explanation out loud into Spanish, then looked at one of the TAs for approval and said, “¿Verdad?' [Right?] The informal manner in which the student acted-by calling aloud a translation in the middle of class-shows his confianza with both the professor and the TA. At the same time this behavior facilitated his classmates' learning in the zone, as they benefited from his translation.

Confianza was evident in the informal register in which students communicated with TAs when asking for help. Students would often call out "iMira a ver chequea ésto?" [Hey come check this out!] or "Ven acá, mira a ver" [Come here, check it out] or simply call the TA's attention with "Meeera" [Hey]. The use of mira-literally look but translated here as hey because it is used to get someone's attention-is informal in the classroom. Even more informal is the form mera, which is a very low register pronunciation of mira. Instead of following the traditionally formal discourse of asking in full sentences and raising their hands, students expected the teaching assistants to know what they were asking for. The expression chequea ésto, is the same as check this out, a colloquial anglicism commonly used in informal settings. The fact that students also referred to the TAs using the omitted pronoun tú (you) also reflects that informal use of language.

Whereas in other classrooms calling out questions and answers to whoever might respond could draw teasing from peers because it shows publicly that the student needs help, in our classroom peer help was accepted, encouraged, and patterned. One example occurred during a class in which students were watching a video about fire ants to assess their listening skills. The video was played first so that students could focus on the visuals and the order of events. Then, the second time, students were given a partial transcript of the video's dialogue with some blanks to be filled in. One of the students, Ferdinand, heard the word "weight" and had an idea of what it meant based on his background knowledge, but he still looked for the professor's approval by calling out “¿Cómo heavyweight?” [Like heavyweight?] Ferdinand had associated the term "weight" as mentioned in the video in reference to fire ants, to another context in which he had heard this word before (he was making reference to how the word is used to classify fighters in boxing matches). The confianza that had been developing among the members of the classroom allowed Ferdinand to feel comfortable enough to ask about the connection he had made in front of the class. This event also contributed to other students' understandings of the word in the emerging zone because Ferdinand shared his question and his connection with the whole class.

\section{Discussion}

Creating a space where students felt comfortable and at ease was crucial for the emergence of confianza in our learning environment. Once students realized that this was a 
safe space, they participated without fear of being wrong or making mistakes. They understood that this was part of their language learning process and that they were going through this journey together. This is why students felt comfortable drawing on their background knowledge to make sense of new material, complete their assignments, and continue learning. There were four aspects of our learning environment that we believe were mainly responsible for these dynamics.

The students had many opportunities for relationship building as they worked together, exchanged ideas, information, and personal experiences. Students soon became better acquainted with each other and learned each other's strengths, so eventually they knew which individuals to turn to for particular questions and tasks. The fluidphysical space of the classroom made it easy for these relationships to be formed since students could easily move to wherever they preferred in the classroom and were encouraged to do so if needed. The fact that the course had an emphasis on bilingualism also contributed greatly to students' participation and contributions because they knew that what mattered most was sharing their knowledge and even questions, not the language in which it was done. Bilingualism also served as an important aspect of the class when students had questions about material or assignments since language was not a barrier for clarification. Lastly, the access students had to the instructors and the rapport that was established between them during the program was also a helpful aspect because there was always someone available to help the students and, as they reported, they did not feel diminished or below (inferior to) any staff member. Some of our examples also demonstrate the informal language and facility with which students communicated with the staff. This, along with the other factors already mentioned, facilitated confianza.

Once confianza had been established it facilitated learning and the zone emerged as a result. There were three characteristics of classroom interactions, which linked confianza to the emergence of the zone. In our classroom (a) students sought and accepted help from professors, teaching assistants, and peers. This showed that they perceived everyone as a resource and relied on peers and staff equally. One of the most interesting dynamics we observed was (b) the unsolicited sharing of information, since students would often answer questions or share strategies with peers. They felt comfortable doing this despite the fact that they were not being requested to help, so if they noticed that a peer had a question and that they could help it was normal for them to interject to provide information and assistance. During the course we also noticed a significant amount of (c) informal discourse used by the students, regardless of who the students were addressing. This made it clear that confianza existed in this class not only among the peers but also when addressing an instructor or staff member. These classroom interactions, facilitated by confianza, were evidence of the emerging zone. 
Though these results are situated within our particular case, they are cause for reflection for other practitioners in similar contexts. We would like to highlight that the acceptance of Spanish in the English classroom, long shunned by ESL practitioners, was a key component to building confianza in our classroom. This shift in practitioners' perspectives from a monolingual ideology to a bilingual ideology, called a translanguaging pedagogy by García and Li (2013) or translingual approach by Canagarajah (2013), built up confianza as students could trust that they could bring all of their linguistic resources to bear without fear of being chastised or silenced. We would recommend a movement toward this kind of pedagogy for any practitioner seeking to build confianza in the classroom.

\section{Conclusion}

The results from our program stress the importance of fostering an environment where students feel comfortable and where asking questions and making mistakes are part of their language learning process. The development of confianza allowed for the emergence of activities that facilitated the activation of students' ZPD and thus facilitated language learning. The strategies implemented in our classroom can be extrapolated into other learning contexts and adapted to the particular needs of educators and students. Creating an environment that fosters confianza can ameliorate the fear or anxiety often experienced by students who are learners of English as a second language. Students learn to respect and trust each other when they understand that their peers are English learners just as they are and that they can all be sources of support for each other.

\section{References}

Canagarajah, S. (2013). Translingual practice: Global Englishes and cosmopolitan realities. London, UK: Routledge.

Emerson, R. M., Fretz, R. I., \& Shaw, L. L. (2011). Writing ethnographic field notes (2nd ed.). Chicago, IL: Unviersity of Chicago Press. http://dx.doi.org/10.7208/chicago/9780226206868.001.0001.

García, O., Flores, N., \& Chu, H. (2011). Extending bilingualism in U.S. secondary education: New variations. International Mulitilingual ResearchJournal, 5(1), 1-18. http://dx.doi.org/10.1080/ 19313152.2011.539486.

García, O., \& Li, W. (2013). Translanguaging: Language, bilingualism and education. New York, NY: Palgrave Macmillan. http:/ /dx.doi.org/10.1057/9781137385765.

Lantolf, J. (2000). Sociocultural theory and second language learning. Oxford, UK: Oxford University Press.

Maldonado, N. I. (2000). The teaching of English in Puerto Rico: One hundred years of degrees of bilingualism. Higher Education in Europe. 25 (4), 487-497. http://dx.doi.org/10.1080/ 03797720120037822 . 
Mazak, C. M. (2008). Negotiating el difícil: Uses of English text in a rural Puerto Rican community. Centro Journal, 20(1), 51-71.

Mazak, C. M., \& Herbas-Donoso, C. (2014). Translanguaging practices and language ideologies in Puerto Rican university science education. Critical Inquiry in Language Studies, 11(1), 27-49. http://dx.doi.org/10.1080/15427587.2014.871622.

Moll, L. C. (2013). L. S. Vygotsky and education. London, UK: Routledge.

Moll, L. C., Amanti, C., Neff, D., \& Gonzalez, N. (2005). Funds of knowledge: Theorizing practices in households, communities, and classrooms. Mahwah, NJ: Lawrence Erlbaum Associates.

Reyes, I. (2009). English language learners' discourse strategies in science instruction. Bilingual Research Journal, 31(1/2), 95-114. http://dx.doi.org/10.1080/15235880802640631.

Torres González, R. (2002). Idioma, bilingüismo y nacionalidad: la presencia del inglés en Puerto Rico [Language, bilingualism, and nationality: The presence of English in Puerto Rico]. San Juan, PR: Editorial de la Universidad de Puerto Rico.

Vélez-Ibáñez, C. G., \& Greenberg, J. B. (1992). Formation and transformation of funds of knowledge among U.S. Mexican households. Anthropology and Education Quarterly, 23(4), 313-335. http://dx.doi.org/10.1525/aeq.1992.23.4.05x1582v.

Vygotsky, L. S. (1978). Mind in society: The development of higher psychological processes. Cambridge: MA: Harvard University Press.

\section{The Authors}

Sandra L. Soto-Santiago is an assistant professor at the University of Puerto Rico, Mayagüez Campus and an associated researcher in CeIBA (Centro para la investigación del bilingüismo y aprendizaje [Center for research on bilingualism and learning]). Her current projects focus on transnationalism and education, translanguaging, and youth.

Rosita L. Rivera is co-director of CeIBA (Centro para la investigación del bilingïismo y aprendizaje [Center for research on bilingualism and learning]) and associate professor in the English Department at the University of Puerto Rico in Mayagüez. Her teaching and research interests are in the fields of applied linguistics, language use and needs of ESL learners.

Catherine M. Mazak is co-director of CeIBA (Centro para la investigación del bilingüismo $y$ aprendizaje [Center for research on bilingualism and learning]) and associate professor of English at the University of Puerto Rico, Mayagüez. She studies bilingualism and translanguaging practices in higher education using ethnographic research methods. 